\title{
CDKN2A gene inactivation in epithelial sporadic ovarian cancer
}

\author{
D Niederacher ${ }^{1}, \mathrm{H}-\mathrm{Y}$ Yan ${ }^{1,2}, \mathrm{H}-\mathrm{X}$ An ${ }^{1}, \mathrm{HG}$ Bender ${ }^{1}$ and MW Beckmann ${ }^{1}$ \\ ${ }^{1}$ Department of Obstetrics and Gynaecology, Heinrich-Heine-University, Moorenstr. 5, 40225 Düsseldorf, Germany; ${ }^{2}$ Department of Obstetrics and Gynaecology, \\ The Third Affiliated Hospital of Hebei Medical University, 16 Weiming Street, 050051 Shijiazhuang, People's Republic of China
}

\begin{abstract}
Summary The tumour suppressor gene CDKN2A, located on chromosome 9p21, encodes the cell cycle regulatory protein p16. Inactivation of the CDKN2A gene could lead to uncontrolled cell growth. In order to determine the role of $C D K N 2 A$ in the development of sporadic ovarian cancer, loss of heterozygosity at 9p21-22, homozygous deletion, mutation and methylation status of the CDKN2A gene as well as CDKN2A expression were examined in a panel of serous papillary ovarian cancer. The frequency of loss of heterozygosity (LOH) for one or more informative markers at 9p21-22 was 65\% (15/23). The most common deleted region was located between interferon (IFN)- $\alpha$ and D9S171. Homozygous deletions and mutations of the CDKN2A gene were not found. There was no evidence of methylation in exon 1, but methylation in exon 2 of CDKN2A gene was found in $26 \%$ (6/23). Absence of CDKN2A gene expression was shown in 27\% (6/22) at mRNA level and $21 \%$ $(4 / 19)$ at protein level. These data suggest that the CDKN2A gene is involved in the tumorigenesis of ovarian cancer, but the mechanisms of $C D K N 2 A$ gene inactivation in serous papillary ovarian cancer remains unclear.
\end{abstract}

Keywords: CDKN2A gene; LOH; 9p21-22; RT-PCR; immunohistochemistry; ovarian cancer

Ovarian cancer (OC) is the leading cause of death in women with gynaecological malignancies. In the USA in 1996 approximately 24000 OC were diagnosed with 13600 deaths, and in Germany 6400 cases with a similar death rate (Beckmann et al, 1996a). Because of the absence of early symptoms the majority of patients are diagnosed with advanced stages. Existing therapeutic measures are often ineffective and the prognosis of the patients is poor.

Molecular genetic alterations play a key role in carcinogenesis. Understanding genetic events that lead to initiation and progression of ovarian cancer remains an important challenge in gynaecological research.

Multiple genetic changes, including activation of protooncogenes and inactivation of tumour suppressor genes, are involved in the genesis and progression of human cancers. Some associations of genetic alterations with $\mathrm{OC}$ development has been reported. Among them the involvement of chromosome 9 is very noticeable. It was first reported by Cliby et al (1993) and confirmed by others using loss of heterozygosity ( $\mathrm{LOH}$ ) analysis (Chenevix-Trench et al, 1994; Osborne and Leech, 1994). The most frequent $\mathrm{LOH}$ region on chromosome 9p is next to D9S171 (Chenevix-Trench et al, 1994; Shih et al, 1997). This indicates a potential tumour suppressor gene in this region involved in the tumorigenesis of ovarian cancer.

The CDKN2A (also called CDKN2, MTS1, CDK4I) gene was identified as a candidate tumour suppressor gene within this

Received 16 September 1998

Revised 26 February 1999

Accepted 11 March 1999

Correspondence to: D Niederacher, Molekulargenetisches Labor der Universitäts-Frauenklinik im BMFZ, Gebäude 23.12.04, Moorenstr 5, 40225 Düsseldorf, Germany chromosomal region (Kamb et al, 1994). It encodes the cyclindependent kinase inhibitor protein p16, a negative cell cycle regulator. Binding of $\mathrm{p} 16$ to $\mathrm{CDK} 4$ prevents the association of CDK4 with cyclin D1. Phosphorylation of substrates essential for G1 transition of the cell cycle is subsequently inhibited (Serrano et al, 1993). Inactivation of the $C D K N 2 A$ gene may therefore lead to uncontrolled cell growth. In primary ovarian cancer, mechanisms of the $C D K N 2 A$ gene inactivation remains unclear. Intragenic mutations and homozygous deletions were shown to be rare events (Campbell et al, 1995; Hatta et al, 1995; Shih et al, 1997). Methylation status and expression pattern were reported mainly with conflicting results (Fujita et al, 1997; Shih et al, 1997). To determine the role of the CDKN2A gene in the development of ovarian carcinoma, $\mathrm{LOH}$ at $9 \mathrm{p} 21$, homozygous deletion, mutation and methylation status of the $C D K N 2 A$ gene as well as its expression at mRNA and protein levels were analysed in a panel of sporadic ovarian tumours.

\section{MATERIALS AND METHODS}

\section{Samples}

Samples used in this study ( $n=33 ; 23$ OCs, ten benign samples) were collected from patients (informed consent) during the time of primary surgery at the Department of Obstetrics and Gynaecology, Heinrich-Heine University, Düsseldorf, Germany. Only serous epithelial carcinoma were included. Pathological grades were $\mathrm{G} 1=$ two, $\mathrm{G} 2=11$ and $\mathrm{G} 3=$ ten cases. Clinical stage of OC patients were stage $\mathrm{I}+\mathrm{II}=$ nine and $\mathrm{III}+\mathrm{IV}=14$ cases. Three benign serous cystoma and seven normal ovarian samples were also analysed. For these samples the superficial cell layers were used. None of the patients received chemotherapy or endocrine treatment prior tumour excision. Surgically removed tissues were snap frozen (liquid nitrogen, $-80^{\circ} \mathrm{C}$ ) for later extraction of DNA 
Table 1 Primers used and PCR conditions

\begin{tabular}{|c|c|c|c|c|c|}
\hline Primer & Sequence & $\begin{array}{l}\text { Length of } \\
\text { PCR product } \\
\text { (bp) }\end{array}$ & $\begin{array}{c}\text { Annealing } \\
\text { temperature } \\
\left({ }^{\circ} \mathrm{C}\right)\end{array}$ & $\begin{array}{l}\text { No. of } \\
\text { cycles }\end{array}$ & Use \\
\hline D9S157 & $\begin{array}{l}\text { AGCAAGGCAAGCCACATTTC } \\
\text { TGGGGATGCCCAAGTAACTATATC }\end{array}$ & $133-155$ & 55 & 28 & $\mathrm{LOH}$ \\
\hline D9S162 & $\begin{array}{l}\text { GCAATGACCAGTTAAGGTTC } \\
\text { AATTCCCACAACAAATCTCC }\end{array}$ & $172-196$ & 55 & 28 & $\mathrm{LOH}$ \\
\hline IFN- $\alpha$ & $\begin{array}{l}\text { GTAAGGTGGAAACCCCCACT'a } \\
\text { TGCGCGTTAAGTTAATTGGTT }\end{array}$ & $138-150$ & 55 & 28 & $\mathrm{LOH}$ \\
\hline D9S942 & $\begin{array}{l}\text { GCAAGATTCCAAACAGTA } \\
\text { CTCATCCTGCGGAAACCATT }\end{array}$ & $100-130$ & 55 & 27 & $\mathrm{LOH}$ \\
\hline D9S171 & $\begin{array}{l}\text { AGCTAAGTGAACCTCATCTCTGTCTa } \\
\text { ACCCTAGCACTGATGGTATAGTCT }\end{array}$ & $159-177$ & 55 & 27 & $\mathrm{LOH}$ \\
\hline D9S126 & $\begin{array}{l}\text { ATTGAAACTCTGCTGAATTTTCTGa } \\
\text { CAACTCCTCTTGGGAACTTGC }\end{array}$ & $225-250$ & 56 & 34 & $\mathrm{LOH}$ \\
\hline D9S169 & $\begin{array}{l}\text { AGAGACAGATCCAGATCCCA } \\
\text { TAACAACTCACTGATTATTTAAGGC }\end{array}$ & $259-275$ & 55 & 28 & $\mathrm{LOH}$ \\
\hline D9S161 & $\begin{array}{l}\text { TGCTGCATAACAAATTACCACa } \\
\text { CATGCCTAGACTCCTGATCC }\end{array}$ & 119-135 & 56 & 32 & $\mathrm{LOH}$ \\
\hline $\begin{array}{l}\text { CDKN2A } \\
\text { Exon } 1\end{array}$ & $\begin{array}{l}\text { GCGCTACCTGATTCCAATTC }^{a} \\
\text { GAAGAAAGAGGAGGGGCTG }\end{array}$ & 340 & 60 & $\begin{array}{l}35 \\
26 \\
32\end{array}$ & $\begin{array}{c}\text { exon } 1 \text { Methyl. } \\
\text { exon } 1 \mathrm{HD} \\
\text { exon } 1 \mathrm{EMD}\end{array}$ \\
\hline $\begin{array}{l}\text { CDKN2A } \\
\text { Exon } 2\end{array}$ & $\begin{array}{l}\text { ACAAGCTTCCTTTCCGTCATа } \\
\text { GCGCACGTCCAGCCGCGCCCCGG }\end{array}$ & 235 & 60 & 26 & exon 2 HD \\
\hline $\begin{array}{l}\text { CDKN2A } \\
\text { Exon? }\end{array}$ & GGAAATTGGAAACTGGAAGC & 509 & 56 & 35 & exon 2 Methyl. \\
\hline $\begin{array}{l}\text { CDKN2A } \\
\text { Exon } 2\end{array}$ & $\begin{array}{l}\text { ACAAGCTTCCTTTCCGTCAT } \\
\text { TCTGAGCTTTGGAAGCTCT }\end{array}$ & 422 & 64 & 32 & exon 2 EMD \\
\hline GAPDH 1 & $\begin{array}{l}\text { TGTGCTCCCACTCCTGATTTC } \\
\text { CAAAGGGCAGGAGTAAAGGTC }\end{array}$ & 200 & & & ref. for fd-PCR \\
\hline $\begin{array}{l}\text { CDKN2A } \\
\text { Expression }\end{array}$ & $\begin{array}{l}\text { GCCCAACGCACCGAATAGTa } \\
\text { CGATGGCCCAGCTCCTCAG }\end{array}$ & 261 & 60 & 37 & expression \\
\hline GAPDH 2 & $\begin{array}{l}\text { CCATGGAGAAGGCTGGGGa } \\
\text { CAAAGTTGTCATGGATGACC }\end{array}$ & 195 & 60 & 27 & ref. for fd-RT-PCR \\
\hline
\end{tabular}

HD, homozygous deletion; Methyl., methylation; ref., reference. aFluorescent labelled.

and RNA (Niederacher et al, 1997). Haematoxylin \& eosin (H\&E) staining was used for routine pathological evaluation. The content of tumour cells in the samples analysed was more than $70 \%$. As a source of normal DNA peripheral blood was used.

\section{LOH analysis of loci 9p21-22}

Eight microsatellite markers at 9p21-22 were analysed. Primers used and polymerase chain reaction (PCR) amplification conditions are shown in Table 1. Primer sequences were obtained from the Genome Data Base (http://www.gdb.org/) and purchased from Pharmacia (Freiburg, Germany). One primer of each pair was (Cy5) fluorescent-labelled at the $5^{\prime}$ end. PCR products were analysed in an automated laser-activated fluorescent DNA sequencer (A.L.F. express, Pharmacia Biotech). The assessment of allele loss were performed as described previously (Niederacher et al, 1997).

\section{Homozygous deletion analysis of CDKN2A gene}

Homozygous deletion (HD) of CDKN2A gene was determined by fluorescent differential PCR (fd-PCR) (An et al, 1995). Glyceraldehyde 3-phosphate dehydrogenase (GAPDH) was used as internal standard. PCR products were analysed in a DNA sequencer and assessment of HD was performed using AlleleLinks software (Amersham Pharmacia Biotech). Deletion status of the first and second exon of $C D K N 2 A$ gene was analysed, respectively. Normal DNA from peripheral blood leucocytes was used as control. Reduction of the ratio $C D K N 2 A$ :GAPDH of more than $50 \%$ compared with that in the normal controls was considered to present a HD.

\section{Mutation analysis of $C D K N 2 A$ gene}

Mutation status of the $C D K N 2 A$ gene was determined by EMD (enzymatic mutation detection) (Del Tito et al, 1998) using Passport $^{\mathrm{TM}}$ Mutation Scanning Kit (Amersham Pharmacia Biotech). EMD was performed according to the protocol provided by the manufacturer. Briefly, $20 \mu 1$ PCR products were denatured at $95^{\circ} \mathrm{C}$ for $5 \mathrm{~min}$ followed by hybridization at room temperature for $30 \mathrm{~min}$. Then, $2 \mu \mathrm{l} \mathrm{T} 4$ Endonuclease VII were added and cleavage was performed at $37^{\circ} \mathrm{C}$ for $30 \mathrm{~min}$. Final products were analysed in a DNA sequencer and assessment was performed using ALFwin ${ }^{\mathrm{TM}}$ Fragment Analyser 1.01 (Amersham Pharmacia Biotech). The mutation status of the first and second exon of $C D K N 2 A$ gene was analysed respectively. Primer used and PCR conditions are shown in Table 1.

\section{Methylation analysis of CDKN2A gene}

The methylation status of $\mathrm{CpG}$ islands within the CDKN2A gene were analysed by PCR-based methylation assay 
(Gonzalez-Zulueta et al, 1995; Lo et al, 1996). Briefly, $1 \mu \mathrm{g}$ of genomic DNA was digested by $10 \mathrm{U}$ SmaI, CfoI or HpaII separately (at $30^{\circ} \mathrm{C}, 37^{\circ} \mathrm{C}, 37^{\circ} \mathrm{C}$ respectively) for $12 \mathrm{~h}$. Thereafter, $10 \mathrm{U}$ enzymes were added and digestion continued for another 12 h. Digested DNA was subjected to PCR. Methylation status of the first and second exon of CDKN2A gene was analysed separately. The primers used (Table 1) amplified exon 1, a $340 \mathrm{bp}$ fragment including one SmaI, four CfoI and two HpaII sites, and exon 2, a 509 bp fragment including one SmaI, seven $C f o$ I and four HpaII sites. GAPDH was co-amplified as an internal control. Digested DNA from normal tissue was used as negative control to ensure that digestion was complete. Undigested DNA was amplified as positive control.

\section{CDKN2A gene mRNA expression}

Total cellular RNA was isolated using TRIZOL (Gibco-BRL, Glasgow, UK). One microgram RNA was subjected to digestion by DNAase I (Gibco-BRL, Rockville, MD, USA) according to the protocol provided by the producer. A total of $0.86 \mu \mathrm{g}$ of the digested RNA was used for cDNA synthesis. Briefly, digested RNA was denatured at $90^{\circ} \mathrm{C}$ for 5 min and transcribed by MulvReverse-Transcriptase (Pharmacia, Freiburg, Germany) using hexanucleotide (random-) primers. Final reaction volume of $20 \mu \mathrm{l}$ contained $50 \mathrm{~mm}$ potassium chloride, $10 \mathrm{~mm}$ Tris- $\mathrm{HCl}, 7.5 \mathrm{~mm}$ magnesium chloride, $0.1 \mathrm{mg} \mathrm{ml}^{-1}$ bovine serum albumin (BSA),

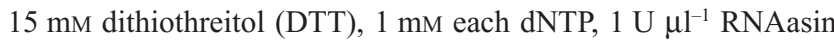
(Promega), $1000 \mathrm{pmol}$ random-primers, 9.5 U Mulv-ReverseTranscriptase. The conditions were: $26^{\circ} \mathrm{C}$ for $10 \mathrm{~min}, 42^{\circ} \mathrm{C}$ for $45 \mathrm{~min}$ and $95^{\circ} \mathrm{C}$ for $5 \mathrm{~min}$. A $2 \mu \mathrm{cDNA}$ aliquot corresponding to $86 \mathrm{ng}$ of RNA was used as template for the reverse transcription PCR (RT-PCR) amplification. Primers used were shown in Table 1. GAPDH was co-amplified as internal standard. To maintain both amplifications (CDKN2A and GAPDH) in the exponential phase a 'drop-in' method was used for the differential RT-PCR. Thirty-seven cycles were performed for $C D K N 2 A$ and 27 cycles for GAPDH. PCR products were analysed in a DNA sequencer and assessment was performed as above. mRNA levels in OC were compared to that in normal ovarian tissues. Expression level below the normal range was considered as low, above the normal range as high expression.

\section{Immunohistochemistry}

Immunohistochemical staining for $C D K N 2 A$ gene product p16 was performed on paraffin-embedded formalin-fixed sections using the indirect avidin-biotin peroxidase method as described previously (Beckmann et al, 1996c). Representative paraffin blocks were sectioned at $5 \mu \mathrm{m}$, affixed to $0.02 \%$ poly-L-lysinecoated slides and dried. Sections were dewaxed in xylene and rehydrated through descending grade alcohol to phosphatebuffered saline (PBS) (pH 7.4), followed by digestion with $0.1 \%$ trypsin for $20 \mathrm{~min}$, incubation in methanol with $0.03 \%$ hydrogen peroxide for $20 \mathrm{~min}$ and $30 \%$ normal horse serum $20 \mathrm{~min}$ at room temperature. Sections were then incubated with mouse antihuman p16 monoclonal antibody (1:300 dilution, Pharmingen, San Diego, CA, USA) overnight at $4{ }^{\circ} \mathrm{C}$. This was subsequently followed by biotinylated horse anti-mouse antibody $(1: 100)$ and by avidin-biotin-peroxidase complex (Vector Laboratories, Burlingame, CA, USA). As negative control, irrelevant mouse monoclonal IgG was applied as the primary antibody. A known p16-positive epithelial tissue sample was used as positive control. Immunoreactivity of p16 was quantified by counting staining positive and negative tumour cells in a minimal total of 1000 cells. The relative number of immunoreactive cells was graded as follows: $<10 \%=-, 10-50 \%=+,>50 \%=++$. Intensity of staining was not evaluated.

\section{Statistical analysis}

Statistical analysis was performed by using SPSS (8.0) software.

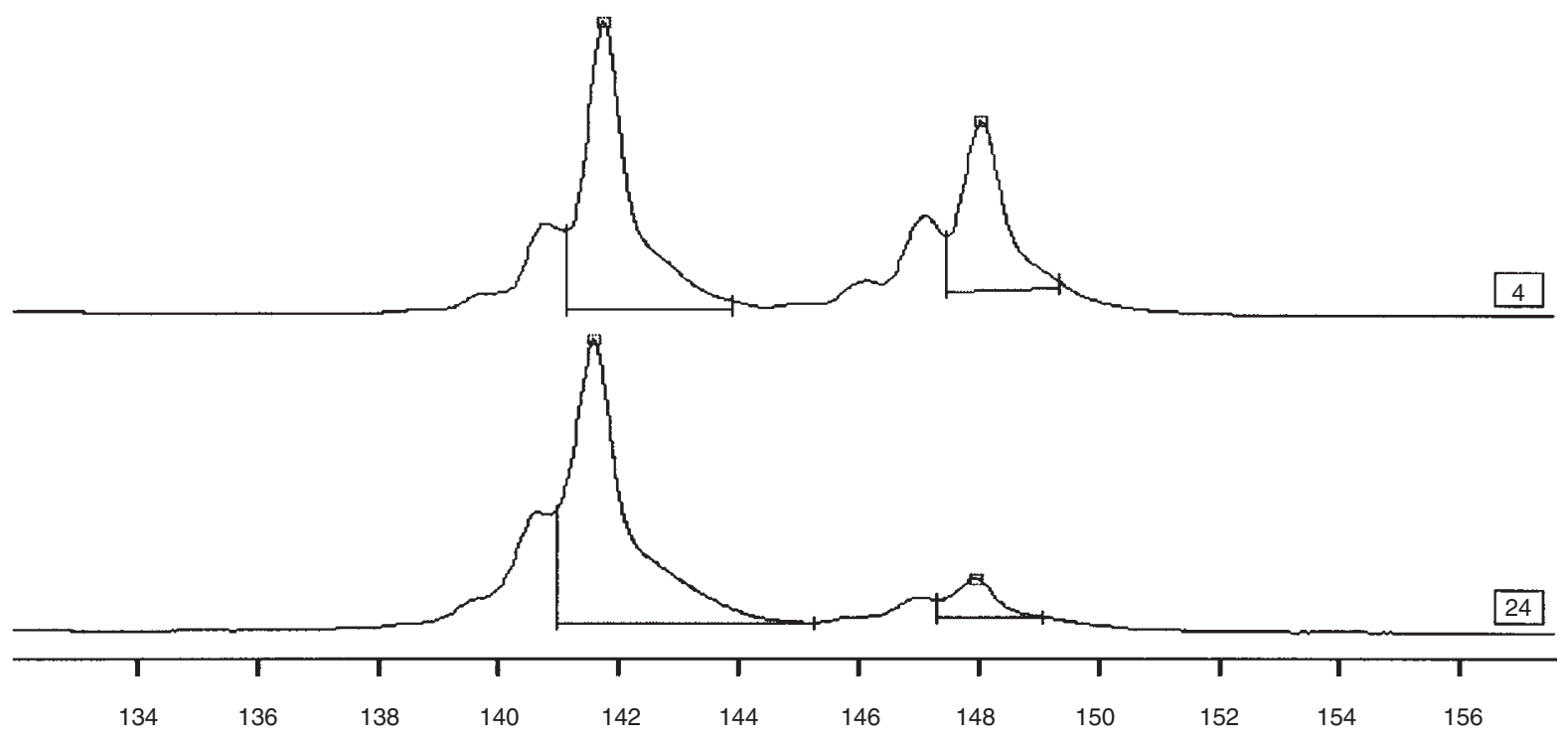

Figure $1 \mathrm{LOH}$ analysis of marker D9S162 ( $x$-axis: run time (min)). Lane 4: normal blood DNA, lane 24: tumour DNA with signal reduction (80\%) in the second allele 


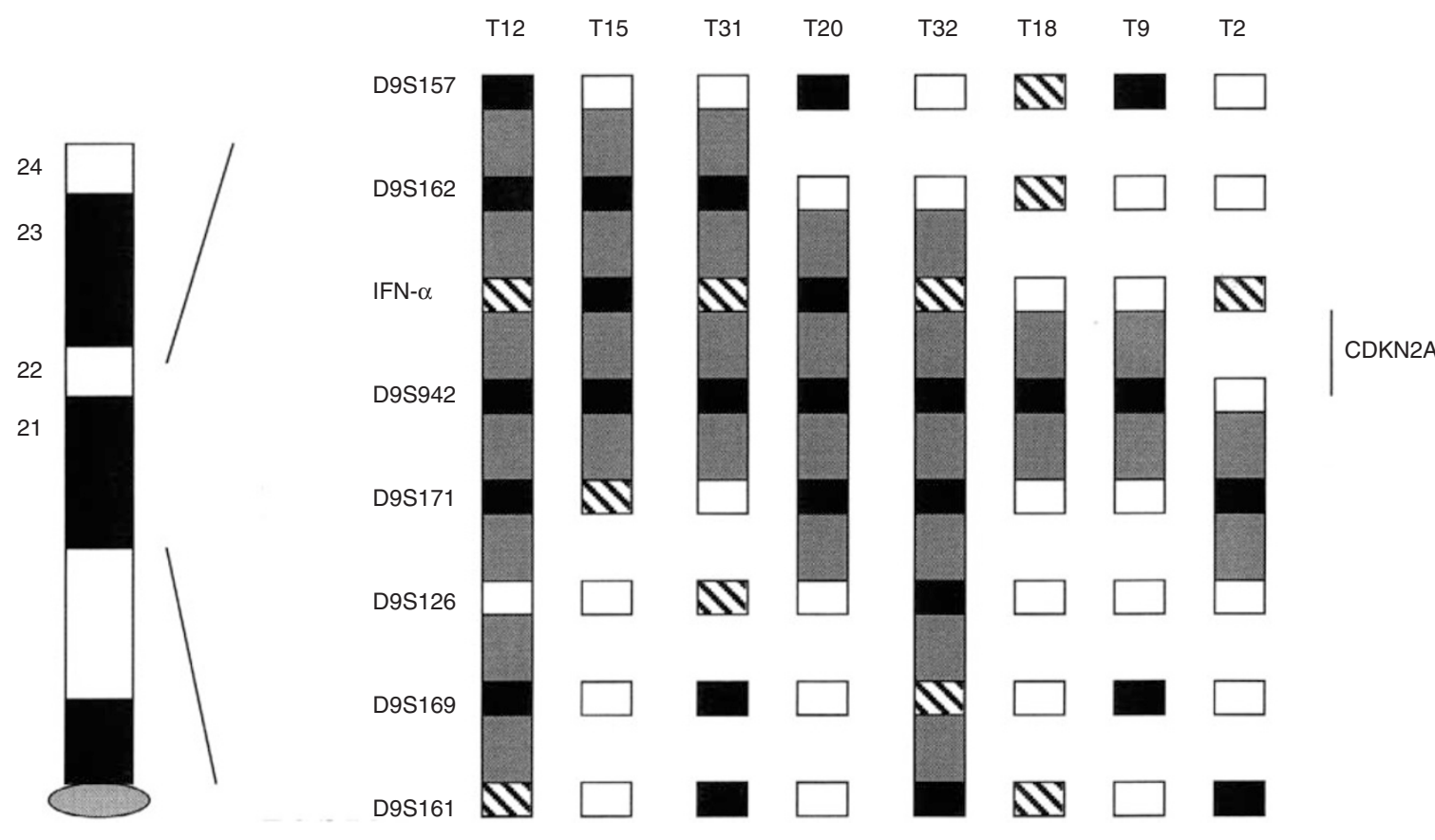

$9 p$

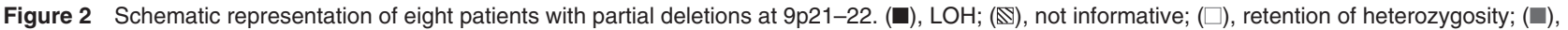
largest possible region of deletion

\section{RESULTS}

\section{LOH on chromosome 9p21-22}

Paired normal and tumour DNA from 23 malignant tumours and three benign tumours were analysed for LOH. No LOH was found in the benign tumours. Of the 23 malignancies analysed, 15 (65\%) showed LOH of at least one or more microsatellite markers. Representative examples of $\mathrm{LOH}$ are shown in Figure 1. Frequencies of $\mathrm{LOH}$ in the tumour panel varied according to the markers tested. D9S157 and D9S169 showed the least frequent (40\%) and D9S942, IFN- $\alpha$ and D9S171 the most frequent LOH rates $(59 \%, 53 \%$ and $53 \%$ of informative cases respectively). In seven of the 15 tumours with allele loss, all informative markers showed $\mathrm{LOH}$, suggesting that in these tumours a large region of 9p21-22 was lost. Eight tumours with partial deletion pattern are illustrated in Figure 2. Most of the tumours (7/8) showed a common region of deletion between marker IFN- $\alpha$ and D9S171 including the $C D K N 2 A$ gene. Only one tumour (T2) with heterozygous marker D9S942 may further restrict the SRO (smallest region of overlap) between markers D9S942 and D9S171, but marker IFN- $\alpha$ is not informative in this tumour (T2). The minimum $\mathrm{LOH}$ rate for the $C D K N 2 A$ gene locus estimated by the extragenic markers (IFN- $\alpha$ and D9S942) was 39\%.

\section{Homozygous deletion and mutation of CDKN2A gene}

Homozygous deletion and mutation status of the CDKN2A gene were analysed in all the tumours. No homozygous deletion was found. There was no evidence of mutation in both exons of the CDKN2A gene.

\section{Methylation of the CDKN2A locus}

Methylation status of exon 1 and 2 of the CDKN2A gene was analysed separately. Of the 33 ovarian samples analysed (23 malignant epithelial tumours, three benign tumours and seven normal ovarian tissue samples), six malignant tumours showed methylation in exon 2, but none showed methylation in exon 1 . Exon 2 methylation did not correlate to pathological grade and clinical stage of the patients and had no association with reduction of mRNA and protein expression of the CDKN2A gene. No methylation was found in both exons in either the benign tumours or the normal ovarian tissues.

\section{Expression of $C D K N 2 A$ gene at mRNA and protein level}

The mRNA level of $C D K N 2 A$ gene was examined in a total of 22 frozen ovarian cancers and seven normal ovarian tissues by differential RT-PCR (Figure 3). Of 22 tumours analysed, low expression of the $C D K N 2 A$ gene was detected in six tumours and high expression in eight tumours. The expression of the $C D K N 2 A$ gene was not significantly associated with histological grade and clinical stage.

The $C D K N 2 A$ gene product p16 was investigated by immunohistochemistry in 19 ovarian cancers and seven normal ovarian tissues. In normal ovarian tissue the epithelium showed weak positive staining. Of the 19 OCs examined, 15 showed positive staining $(+/++)$ and four tumours were negative. The immunostaining correlated with $C D K N 2 A$ mRNA level $(P=0.038$, Table 2 ), but was not significantly associated with pathological grade and clinical stage of patients (data not shown).

$C D K N 2 A$ gene expression (mRNA and protein) and LOH at $C D K N 2 A$ gene locus (D9S942 and IFN- $\alpha$ ) were not significantly associated (Table 3 ). 


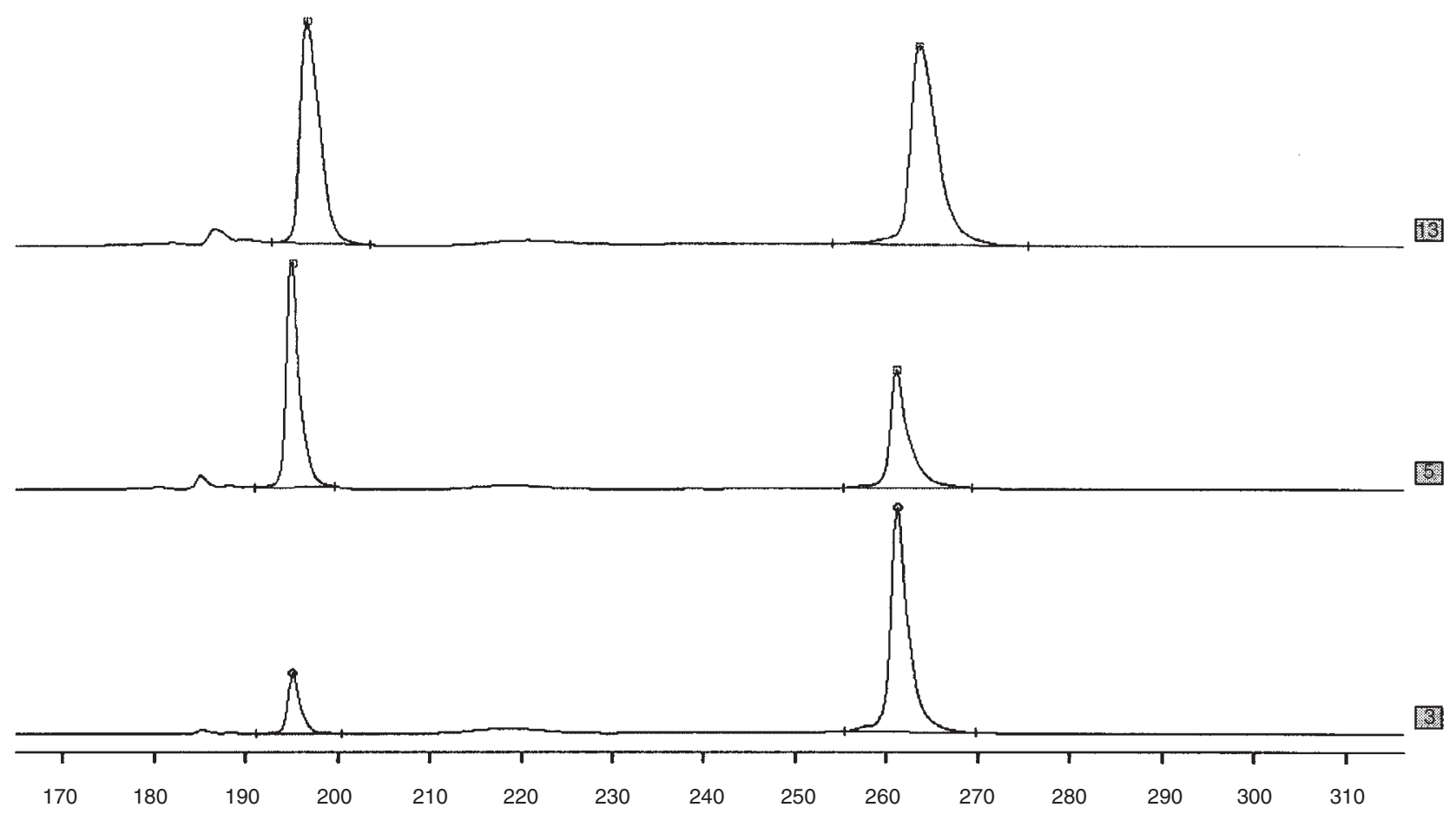

Figure $3 C D K N 2 A$ expression analysis by fd-RT ( $x$-axis: base pair) in ovarian cancer. First peak: reference gene GAPDH (195 bp), second peak: $C D K N 2 A$ gene (261 bp). Lane 13: normal ovarian tissue, lane 5: ovarian cancer (T15) showed low expression (signal reduced $58 \%$ compared to normal ovarian tissues), lane 3: ovarian cancer (T10) showed high expression (signal increased three-fold compared to normal ovarian tissues)

Table 2 Relationship between CDKN2A mRNA and protein expression $(n=18)$

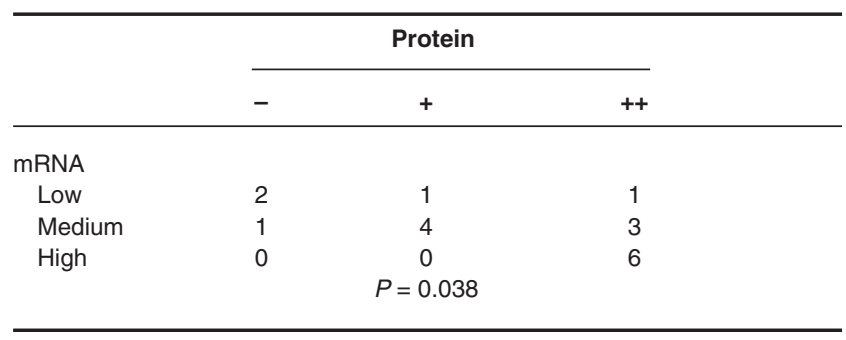

By $\chi^{2}$ test.

\section{Discussion}

LOH studies have been widely used to identify chromosome regions which may contain putative tumour suppressor genes. Frequent LOH on chromosome 9p has been observed in multiple tumour types including sporadic ovarian cancer. This indicates the presence of tumour suppressor gene(s) in this region involved in the tumorigenesis in a wide variety of tumours (Eiriksdottir et al, 1995; Kishimoto et al, 1995; Schultz et al, 1995; Devlin et al, 1996). In this study, LOH analysis at eight loci of 9p21-22 was performed in 23 serous papillary OCs by using a sensitive analytical method based on fluorescent PCR technology (Beckmann et al, 1996b; Niederacher et al, 1997). LOH at 9p was demonstrated in 15 of $23(65 \%)$ tumour samples. A most common deleted region could be defined between IFN- $\alpha$ and D9S171; this is in good agreement with previous observations (Chenevix-Trench et al, 1994). The high frequency of $\mathrm{LOH}$ at 9p21 gives a strong hint to a
Table 3 Relationship between CDKN2A gene expression and $\mathrm{LOH}$ at CDKN2A locus

\begin{tabular}{lccccccc}
\hline & \multicolumn{3}{c}{ mRNA } & & & \multicolumn{3}{c}{ protein } \\
\cline { 2 - 4 } \cline { 5 - 7 } & Low & Medium & High & & - & + & ++ \\
\hline LOH & 1 & 4 & 2 & & 2 & 3 & 3 \\
No LOH & 5 & 4 & 6 & & 2 & 2 & 7 \\
& & $P>0.05$ & & & $P>0.05$ & \\
\hline
\end{tabular}

By $\chi^{2}$ test.

tumour suppressor gene(s) located in this region, which is involved in the tumorigenesis of sporadic ovarian carcinomas.

The CDKN2A gene is the most common candidate gene in this region. It has been found to be inactivated by intragenic mutations and homozygous deletions in a variety of tumour-derived cell lines such as lung cancer, oesophagus cancer, malignant melanomas and gliomas (Chenevix-Trench et al, 1994; Kamb et al, 1994; Nobori et al, 1994). However, for most primary tumours including OC, mutations and homozygous deletions have been found to be much less frequent than in cancer cell lines (Cairns et al, 1994; Spruck et al, 1994; Campbell et al, 1995; Shih et al, 1997). More interestingly, in sporadic OC, $C D K N 2 A$ mutations strongly associate with specific tumour subtypes. High frequency of mutation was found in mucinous and endometrioid $\mathrm{OC}$, but very low in serous papillary OC (Milde-Langosch et al, 1998). Our study is in good agreement with this finding. Of 23 serous papillary OCs no mutation was found by using EMD, a novel mutation detection technique, 
which has been used as routine scanning method for $B R C A 1 / 2$ mutation in our laboratory. Homozygous deletion has been shown to be very rare in primary tumours including $\mathrm{OC}$, regardless of the tumour subtype (Fujita et al, 1997; Milde-Langosch et al, 1998). In this study no homozygous deletion was found in 23 serous papillary OCs analysed. This further confirms that homozygous deletion does not seem to be a mechanism of CDKN2A gene inactivation in sporadic OC.

Beside mutation and homozygous deletion, an alternative pathway involving hypermethylation of the $5^{\prime} \mathrm{CpG}$ island has been found to inactivate the $C D K N 2 A$ gene by blocking $C D K N 2 A$ transcription in a variety of tumours (Merlo et al, 1994; Costello et al, 1996; Lo et al, 1996). Methylation status of the CDKN2A gene in OC has been rarely reported and with conflicting results: no methylation (0/50) (Shih et al, 1997) and 14\% (8/43) (Fujita et al, 1997). A recent study (Milde-Langosch et al, 1998) showed that methylation also seemed to be specific for tumour histological subtype. It presents much higher frequency in mucinous and endometrioid subtype than in serous papillary OC. To gain further insight to the possible role of $C D K N 2 A$ gene methylation in ovarian carcinogenesis $\mathrm{CpG}$ island methylation status in exon 1 and 2 of the $C D K N 2 A$ gene was investigated. In 23 serous papillary OCs analysed there was no evidence of methylation in exon 1. However, methylation of the second exon was found in seven cases. Methylation of exon 1 is considered to completely block the CDKN2A gene transcription (Merlo et al, 1995), but the mechanism of action of exon 2 methylation remains unclear (GonzalezZulueta et al, 1995). In this study exon 2 methylation existed only in ovarian malignancy, but not in normal ovarian tissue and benign tumours. This implies that exon 2 methylation is to some extent involved specifically in the malignant transformation. Correlation of exon 2 methylation with gene expression level was not found suggesting that other mechanisms than transcriptional suppression may be involved.

Although conventional inactivation mechanisms of the CDKN2A gene, such as mutation, homozygous deletion and 5 -CpG island methylation rarely occurred in serous papillary OC, we found that absence of $C D K N 2 A$ gene expression was not a rare event in these tumours with $27 \%(6 / 22)$ at mRNA level and $21 \%$ (4/19) at protein level. Among six tumours without CDKN2A mRNA expression, none of the known inactivation mechanisms could be detected, suggesting that other mechanisms than those examined might be involved. Interestingly, this study showed a tendency that high $C D K N 2 A$ expression correlated to higher pathological grade and advanced clinical stage, which is in agreement with Fujita et al (1997) and Dong et al (1997). Fujita et al investigated $C D K N 2 A$ expression in 60 OCs and concluded that loss of p16 correlated to longer survival. Dong et al showed in a much larger immunohistochemical study including 190 epithelial ovarian tumours that loss of p16 is associated with lower pathological grade, earlier clinical stage and better prognosis. Similar results were also shown by Shigemasa et al (1997) and MildeLongosch et al (1998). These findings seem to be controversial to the negative regulatory function of p16 in cell cycle control and suggest unknown inactivating mechanisms of the CDKN2A gene in OC. Obviously, genomic alterations at DNA level such as deletion, mutation and methylation influence $C D K N 2 \mathrm{~A}$ gene expression significantly. On the other hand, p16 is in a complicated feedback loop constituted by CDK4, cyclin D1, pRb and some transcriptional factors, which can regulate $C D K N 2 A$ gene expression at transcription level (Serrano et al 1993; Kamb et al, 1994).
Besides this, other bypassing pathways such as cyclin E1 is also supposed to regulate p16 expression indirectly (Gray-Babin et al, 1996). Therefore, it could be interpreted that reduced CDKN2A gene expression may play a key role in the early development of OC. With the progression during OC expression of the CDKN2A gene might be regulated by: (1) other cancer-related gene(s) involved and (2) some transcriptional factors changing with cell proliferation. Therefore, the level of $C D K N 2 A$ gene expression is actually an indicator for the cell status. This interpretation is further supported by the result that $\mathrm{LOH}$ at $C D K N 2 A$ locus does not correlate with $C D K N 2 A$ mRNA level. $C D K N 2 A$ gene mRNA level correlated significantly with the protein level, further indicating that post-transcriptional regulation of protein level does not seem to play a role in the $C D K N 2 A$ expression.

Our result showed that the SRO flanked widely from D9S171 to D9S942 and IFN- $\alpha$. Besides the CDKN2A gene there could be other tumour suppressor gene(s) involved in the tumorigenesis of $\mathrm{OC}$, such as the $\mathrm{p} 15$ gene or $\mathrm{p} 19$ gene, a novel tumour suppressor gene sharing exon 2 with the $C D K N 2 A$ gene.

In conclusion, the results in this study suggest that there is a tumour suppressor gene(s) at $9 \mathrm{p} 21$ involved in the tumorigenesis of OC. The $C D K N 2 A$ gene may be the candidate gene in this region. The inactivation of this gene showed to be tumour subtype specific. In mucinous and endometrioid OC mutation and methylation present the major inactivation mechanisms. But in serous papillary OC the inactivation mechanism remains unclear.

\section{ACKNOWLEDGEMENTS}

The authors would like to thank the technicians of the laboratory of molecular genetics (Ms D Larbig) and of the laboratory of pathomorphology (Ms H Fröhlich; Ms U Grolik), Frauenklinik, Heinrich-Heine Universität, Düsseldorf, Germany, for the recruitment of the tumours, their expert technical assistance and persistent support.

\section{REFERENCES}

An HX, Niederacher D, Beckmann MW, Göhring UJ, Scharl A, Picard F, van Roeyen C, Schnürch HG and Bender HG (1995) ERBB2 gene amplification detected by fluorescent differential polymerase chain reaction in paraffinembedded breast carcinoma tissues. Int $J$ Cancer 74: 57-63

Beckmann MW, An H-X, Niederacher D, Köhrer K, Finken-Eigen M, Schröder W, Schnürch HG and Bender HG (1996a) Oncogene amplification in archival ovarian carcinoma detected by fluorescent differential polymerase chain reaction - a routine analytical approach. Int J Gynecol Cancer 6: 291-297

Beckmann MW, Picard F, An HX, van Roeyen CR, Dominik SI, Mosny DS, Schnürch HG, Bender HG and Niederacher D (1996b) Clinical impact of detection of loss of heterozygosity of BRCA1 and BRCA2 markers in sporadic breast. Br J Cancer 73: 1220-1226

Beckmann MW, Niederacher D, Massenkeil G, Tutschek B, Beckmann A, Schenko G, Schnürch HG and Bender HG (1996c) Expression analyses of epidermal growth factor receptor and HER-2/neu: no advantage of prediction of recurrence or survival in breast cancer patients. Oncology 53: 441-447

Cairns P, Mao L, Merlo A, Lee DJ, Schwab D, Eby Y, Tokino K, van der Riet P, Blaugrund JE and Sidransky D (1994) Rates of p16 (MTS1) mutations in primary tumors with 9p loss. Science 265: 415-416

Campbell IG, Foulkes WD, Beynon G, Davis M and Englefield P (1995) LOH and mutation analysis of CDKN2 in primary human ovarian cancers. Int $J$ Cancer 63: $222-225$

Chenevix-Trench G, Kerr J, Friedlander M, Hurst T, Sanderson B, Coglan M, Ward B, Leary J and Khoo SK (1994) Homozygous deletions on the short arm of chromosome 9 in ovarian adenocarcinoma cell lines and loss of heterozygosity in tumors. Am J Hum Gene 55: 143-149 
Cliby W, Ritland S, Hartmann L, Dodson M, Halling KC, Keeney G, Podratz KC and Jenkins RB (1993) Human epithelial ovarian cancer allelotype. Cancer Res 53: $2393-2398$

Costello JF, Berger MS, Huang HS and Cavenee WK (1996) Silencing of p16/CDKN2 expression in human gliomas by methylation and chromatin condensation. Cancer Res 56: 2405-2410

Del Tito BJ Jr, Poff HE 3rd, Novotny MA, Cartledge DM, Walker RI II, Earl CD and Bailey AL (1998) Automated fluorescent analysis procedure for enzymatic mutation detection. Clin Chem 44: 731-739

Devlin J, Elder PA, Gabra H, Steel CM and Knowles MA (1996) High frequency of chromosome 9 deletion in ovarian cancer: evidence for three tumoursuppressor loci. Br J Cancer 73: 420-423

Dong Y, Walsh MD, McGuckin MA, Gabrielli BG, Cummings MC, Wright RG, Hurst T, Khoo SK and Parsons PG (1997) Increased expression of cyclindependent Chinese inhibitor $2(\mathrm{CDKN} 2 \mathrm{~A})$ gene product P16INK4A in ovarian cancer is associated with progression and unfavourable prognosis. Int J Cancer (Pred Oncol) 74: 57-63

Eiriksdottir G, Sigurdsson A, Jonasson JG, Agnarsson BA, Sigurdsson H, Gudmundsson J, Bergthorsson JT, Barkardottir RB, Egilsson V and Ingvarsson S (1995) Loss of heterozygosity on chromosome 9 in human breast cancer: association with clinical variables and genetic changes at other chromosome regions. Int J Cancer 64: 378-382

Fujita M, Enomoto T, Haba T, Nakashima R, Sasaki M, Yoshino K, Wada H, Buzard GS, Matsuzaki N, Wakasa K and Murata Y (1997) Alteration of p16 and p15 genes in common epithelial ovarian tumors. Int J Cancer 74: 148-1550

Gray-Bablin J, Zalvide J, Fox MP, Knickerbocker CJ, DeCapiro JA and Keyomarsi K (1996) Cyclin E, a redudant cyclin in breast cancer. Proc Natl Acad Sci USA 93: $15215-15220$

Gonzalez-Zulueta M, Bender CM, Yang AS, Nguyen T, Beart RW, Van Tornout JM and Jones PA (1995) Methylation of the $5^{\prime} \mathrm{CpG}$ island of the p16/CDKN2 tumor suppressor gene in normal and transformed human tissues correlates with gene silencing. Cancer Res 55: 4531-4535

Hatta Y, Hirama T, Takeuchi S, Lee E, Pham E, Miller CW, Strohmeyer T, Wilczynski SP, Melmed S, Koeffler HP Kamb A, Gruis NA, Weaver-Feldhaus J, Liu Q, Harshman K, Tavtigian SV, Stockert E and Day (1995) Alterations of the p16 (MTS1) gene in testicular, ovarian, and endometrial malignancies. J Urol 154: 1954-1957

RS 3rd, Johnson BE and Skolnick MH (1994) A cell cycle regulator potentially involved in genesis of many tumor types. Science 264: 436-440
Kishimoto Y, Sugio K, Hung JY, Virmani AK, McIntire DD, Minna JD and Gazdar AF (1995) Allele-specific loss in chromosome 9p loci in preneoplastic lesions accompanying non-small-cell lung cancers. J Natl Cancer Inst 87: 1224-1229

Lo KW, Cheung ST, Leung SF, van Hasselt A, Tsang YS, Mak KF, Chung YF, Woo JK, Lee JC and Huang DP (1996) Hypermethylation of the p16 gene in nasopharyngeal carcinoma. Cancer Res 56: 2721-2725

Merlo A, Herman JG, Mao L, Lee DJ, Gabrielson E, Burger PC, Baylin SB and Sidransky D (1995) 5' GpG island methylation is associated with transcriptional silencing of the tumor suppressor p16/CDKN2/MTS1 in human cancers. Natl Med 1: 686-692

Milde-Langosch K, Ocon E, Becker G and Loning T (1998) p16/MTS1 inactivation in ovarian carcinomas: high frequency of reduced protein expression associated with hyper-methylation or mutation in endometrioid and mucinous tumors. Int J Cancer 79: 61-65

Niederacher D, Picard F, van Roeyen C, An HX, Bender HG and Beckmann MW (1997) Patterns of allelic loss on chromosome 17 in sporadic breast carcinomas detected by fluorescent-labeled microsatellite analysis. Genes Chromosomes Cancer 18: 181-192

Nobori T, Miura K, Wu DJ, Lois A, Takabayashi K and Carson DA (1994) Deletions of the cyclin-dependent kinase-4 inhibitor gene in multiple human cancers. Nature (Lond) 368: 753-756

Schultz DC, Vanderveer L, Buetow KH, Boente MP, Ozols RF, Hamilton TC and Godwin AK (1995) Characterization of chromosome 9 in human ovarian neoplasia identifies frequent genetic imbalance on $9 \mathrm{q}$ and rare alterations involving 9p, including CDKN2. Cancer Res 55: 2150-2157

Serrano M, Hannon GJ, Beach D (1993) A new regulatory motif in cell-cycle control causing specific inhibition of cyclin D/CDK4. Nature 366: 704-707

Shigemasa K, Hu C, West CM, Clark J, Parham GP, Parmley TH, Korourian S, Baker VV and O'Brien TJ (1997) p16 overexpression: a potential early indicator of transformation in ovarian carcinoma. J Soc Gynecol Investig 4: 95-102

Shih YC, Kerr J, Liu J, Hurst T, Khoo SK, Ward B, Wainwright B and ChenvevixTrench G (1997) Rare mutations and to hypermethylation at the CDKN2A locus in epithelial ovarian tumours. Int J Cancer 70: 508-511

Spruck CH 3rd, Gonzalez-Zulueta M, Shibata A, Simoneau AR, Lin MF, Gonzales F, Tsai YC and Jones PA (1994) p16 gene uncultured tumours. Nature (Lond) 370: 183-184 